\section{Graft-transmissible Induction of Elongation and Flowering in Scions of Sugar-beet bred for Resistance to Bolting}

Graft-Transmissible flower induction in scions has been demonstrated for many plants, but in the case of scions requiring vernalization has been described only for

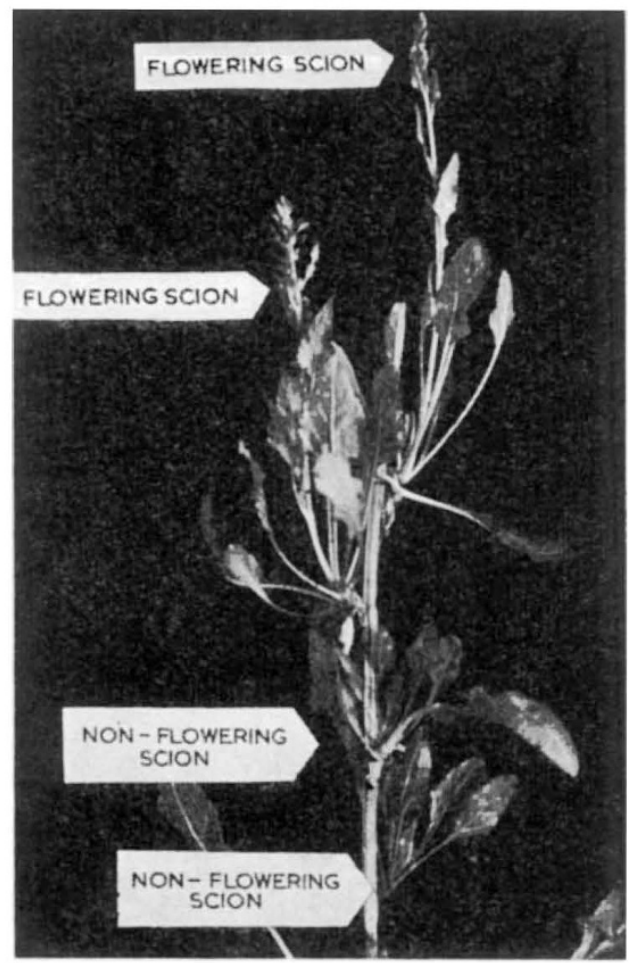

Fig. 1

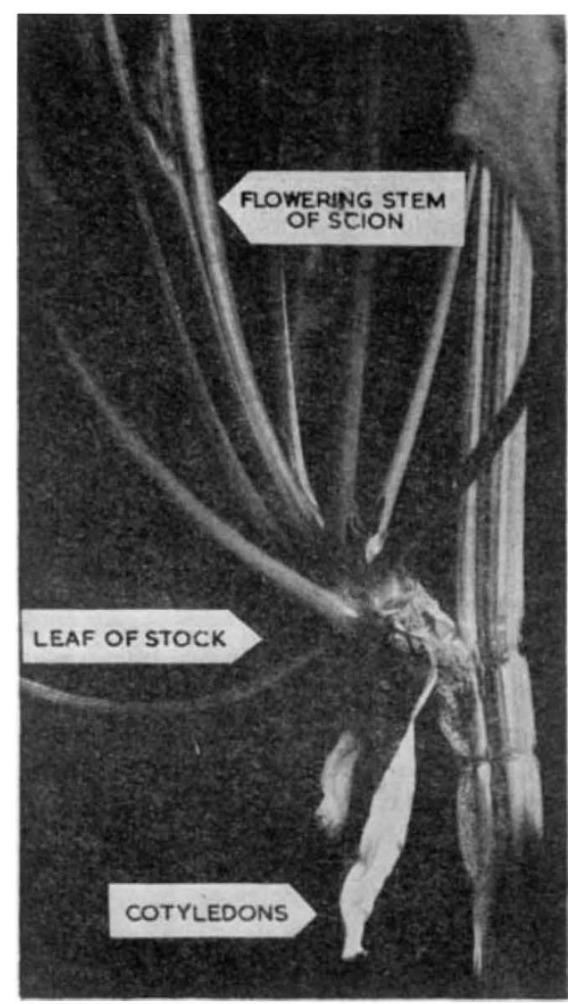

Fig. 2 henban $\theta^{1,2}$ and turnip-rape ${ }^{3}$. Previous attempts to demonstrate this phenomenon in sugar-beet have only been successful when the scion was kept in the dark ${ }^{4}$.

On May 10, 1963, in a humidity chamber in the glasshouse, six scions of an inbred line of diploid sugar-beet selected for resistance to bolting were inserted, when at early cotyledon stage, into leaf-axils on the twelve-inch scape of an autotetraploid stock on which flower buds were already visible. This stock had been vernalized for twelve weeks at $5-10^{\circ} \mathrm{C}$ in continuous light and grown on for four weeks. Three days after grafting, the stock was pruned to the node above the uppermost scion. Although this scion failed and was removed, the remainder flourished. A month after grafting, internodal stem elongation was evident in the two scions now uppermost. First flowers opened on the forty-fourth day and were fertile and diploid (Fig. 1). These scions produced six and eight leaves, respectively, before elongation. In Fig. 2 the lower of these two scions shows its two cotyledons, eight 'radical' leaves and part of the flowering stem on the forty-sixth day.

\section{G. J. Curtis}

K. G. HORNSEY

THE main difference between this and other grafting experiments described in the literature appears to lie in the physiological ages of the scion and stock. In Russian work on vegetative hybridization, scions at the 4-6-leaves stage are held to be most susceptible to the influence of stocks of the same age. Here, however, it may be that the scion has not yet reached the stage of physiological development at which it would require the normal sequence of external factors to become vernalized and ready to flower in the appropriate conditions. The possible acceleration of breeding programmes involving bolting-resistant varieties must await the results of further experiments.

\section{G. K. G. Campbeld}

Plant Breeding Institute, Trumpington,
Cambridge.

${ }^{1}$ Melchers, G., Natursoiss., 26, 296 (1938).

Melchers, G., Ber. deutsch. bot. Ges., 57, 29 (1939).

'Chaliachan, M., and Hlopenkova, L. P., C.R. Acad. Sci. U.R.S.S., 112 , 774 (1956).

- Margara, J., Ann. Inst. nat. Rech. agron., Paris, B, 10, 361 (1960).

\section{Hollow Stem in Very Young Celery Plants}

Houlow stem or pithiness disorder of celery was first reported by Sandsten and White ${ }^{1}$ and Austin and White ${ }^{2}$ as a hereditary condition in which all petioles of affected plants were pithy or hollow from the earliest stages of growth. Emsweller's ${ }^{3}$ investigations of this disorder showed that the hereditary type of pithiness was due to the action of a single dominant gene.

He also found that a second type of pithiness occurred in which the petioles became pithy with increased maturity of the plant. Further work by Coyne ${ }^{4}$ on this second type showed that pithiness generally developed first in the base of the outer petioles and also in that portion of the petiole above the first node. This latter type of pithiness was reported by Sayre ${ }^{5}$ to be associated with a breakdown of the parenchyma cells leaving large air spaces in the petioles.

During the course of work on the varietal susceptibility of self-blanching celery to pithiness a cellular breakdown was observed in 12-week-old celery plants-then at the planting-out stage. Two varieties, 'Utah 15' and 'Utah Golden Crisp', were affected, but when plants were examined a week later, 'Latham Blanching', 'Golden Self-Blanching', 'Stoutheart' and 'Golden Marvel' were all affected, but to different degrees. The affected regions in all varieties 